\title{
Using ICT to Enhance the Management of the Natural \& Cultural Heritage Resources of Old Oyo National Park for E-Tourism Development
}

\author{
Oladeji Sunday Oladipo ${ }^{1}$, Olabode Olatubosun ${ }^{2}$, Iwasokun Gabriel Babatunde ${ }^{2}$ \\ ${ }^{1}$ Dept. Ecotourism and Wildlife Management,Federal University of Technology, Akure Nigeria. \\ ${ }^{2}$ Dept. Computer Science, Federal University of Technology, Akure Nigeria.
}

\begin{abstract}
This paper describes the conceptualization of Old Oyo National Park seeking an intervention for improve collaboration and communication internally across functional and departmental boundaries through the use of ICT. Eighteen natural and cultural heritage resources of ecotourism values were indentified in the Park, in addition to the nine art and craft practiced in these communities and eight annual cultural events. A detail assessment of the level of development of the cultural and natural features in the Old Oyo National Park was carried out based on the three component of tourist destination, viz; attraction, amenities and accessibility. The gridded map of the locations of these ecotourism features was also presented. An e-tourism designed for the park has the basic component of catalog of product, shopping cart, and check out, payment gateway (payment processing network), customer account, internet merchant account and business account. Customers can browse the catalog of tourism product and shops cart it. The gateway component accepts credit card details and sends to the payment gateway for authorization on the premise of adequate security using the SSL primitives. Funds are reserved into the customer account and later transfer to merchant account, and then to the business account of the park.
\end{abstract}

Keywords: Old Oyo National Park, tourism, culture, heritage, ecommerce,

\section{INTRODUCTION}

The study of e-commerce in the tourism industry has emerged as a frontier area for information technology. E-commerce as defined in Turban, Lee, King \& Chung, (2000); Bocij, Greasley and Hickie (2008) is the process of buying and selling or exchanging products, services and information via computer networks including the Internet. Tourism and e-commerce consists primarily of the distributing, buying, selling, marketing and servicing of products or services over electronic systems such as the Internet and other computer networks. It can sometimes involve electronic funds transfer (Donal, Michael \& Hitesh, 2001), supply chain management, e-marketing, online marketing, online transaction processing, electronic data interchange (EDI), automated inventory management systems and automated data collection systems (Popescu Delia 2007). It typically uses electronic communication technology such as the Internet, extranet, e-mail, e-books, database, and mobile phones.

The emergence of the Internet as a tool for the business-to-consumer aspect of e-commerce has far reaching ramifications. Most importantly, it has created opportunities for businesses to reach out to consumers in a very direct way and create electronic markets (Inge M. Kloppiing \& Earl McKinney 2004).
Generally as presented in Deepthi (2008), the revolution in ICTs has profound implications for economic and social development. It has pervaded every aspect of human life whether it is health, education, economics, governance, entertainment etc. Dissemination, propagation and accessibility of these technologies are viewed to be integral to a country's development strategy. The most important benefit associated with the access to the new technologies is the increase in the supply of information. Secondly it reduces the cost of production. Thirdly it has overcome the constraints of distance and geography and fourthly it has led to more transparency (Deepthi 2008). The government of Nigeria is poised at integrating ICTs to all sectors and developmental activity. Tourism is one such potential areas.

Tourism is now being considered as the World's largest industry Nigerian Tourism Development Master Plan, (NTDMP, 2006). Besides export earnings, international tourism generates an increasingly significant share of government (national and local) tax revenues throughout the World. In addition, the development of tourism as a whole is usually accompanied by considerable investments in infrastructure such as airports, roads, water and sewage facilities, telecommunications and other public utilities. Such infrastructural improvements not only generate economic benefits to tourists but can also contribute to improving the living conditions of the local populations (Frederico, 2003). Old Oyo National Park like any other National Park in the World is a protected area with abundant natural resources of immensurable socio-economic, cultural and ecological values. Most protected areas in Nigeria are endowed with natural and cultural resources that if develop could support other tourism activities such as the development of cultural tourism, heritage tourism, cultural heritage tourism, creative tourism, agrotourism, aquatourism and other ecological tourism activities like game viewing, bird watching, Adventure/wilderness experience, Sport fishing tourism (Ormsby and Mannle 2006).

However, these values may be elusive if handled or treated with impunity, indiscriminate and non-challant attitude. It is recorded in Oladeji et. al, (2011), that the ongoing effort at involving community in the management of natural resources in protected areas will go a long way towards achieving sustainable management of these resources thus ensure maximum benefits derivable. These desirable benefits could also be appreciated if information communication technology (ICT) is employed in the management.

Many research scholars ( Ayodele 1988, Fadare 1989, Falade 1993, Adeyemo, 1993, Afolayan et. al. 1996, Adetoro 2002 and Alarape 2001) had carried out studies on Old Oyo National Park since its inception as Upper Ogun Game reserves and National Park in 1991. The results findings had provided useful information on the ecological resources of the Park. Passage of time therefore has made it necessary for the appraisal, review, modification and update of some of the management tools and data generated in line with the current global practices in natural resources management and 
ecotourism development. In order for the ecotourism potentials of the Park to be maximized, there is need for the emergence of appropriate, reliable, detailed and accurate up to date data on the anthropological, anthropogenic, Natural and Historical Cultural heritage resources using the ICT.

George and Reid (2005) express culture as those physical, intangible, abstract, social and psychological aspects that have traditionally held deep significance value and meaning to a community. Therefore, there is the need to develop a framework on using ICT to enhance the management of the natural and cultural heritage resources of Old Oyo National park for ecotourism development. This will involve the design and development of an ecommerce site and the presentation of gridded digital maps of the park using the Global Positioning System and Geographic Information System Techniques to assist tourists have virtual access to these resources from any part of the world (Fig. 2). A Database of the anthropological, anthropogenic, natural, cultural, archeological and historical heritage resources in and around Old Oyo National Park is being developed and will be useful to update the Ecological Management Plan of the Park and develop Ecotourism Management Plan, which will be of tremendous economic benefits to the management of the park, the host communities, National Park Service, Nigerian Tourism Development Corporation and Nigerian Government.

\section{MATERIALS AND METHODS}

\subsection{Background literature on Old Oyo National Park}

Old Oyo National Park is geographically located between North latitudes $8^{0} 10^{\prime}$ and $9^{0} 05^{\prime}$, and East longitudes $3^{0} 35^{\prime}$ and $4^{0} 21^{\prime}$, and centered on North latitude $8^{0} 36^{\prime} 00^{\prime \prime}$ and East longitude $3^{\circ} 57^{\prime} 05^{\prime}$ '. Politically, the park lies in Oyo State in the Southwest of Nigeria and borders Kwara State in the Northeast. It is surrounded by ten (10) Local Government Areas in Oyo State namely: Atiba, Atisbo, Irepo(Kisi), Iseyin, Itesiwaju (Otu), Olorunsogo(Igbeti), Oorelope( Igboho), Orire( Ikoyi), Oyo West and Shaki East, and Kaima Local Government Area in Kwara State. Figure 1 shows the location of Old Oyo National Park with the adjourning communities. Old Oyo National Park covers a land area of approximately 2,512 square kilometers making it the fourth largest national park in Nigeria.

There are three watersheds in Old Oyo national Park, that of River Ogun and its numerous tributaries, that of River Tessi and its tributaries and that of River Iwa and its tributaries. Ogun River flows southwards to the Atlantic Ocean. Several tributaries notably Oopo, Iwawa, Oowe and Owu flow southwestwards and southeastwards to join it before its exit from the park. The Tessi River flows northwards to the River Niger. Three main tributaries including River Soro join it before its exist from the park. The Iwa River flows northeastwards to the River Niger.

The construction of a dam at Ikere Gorge on the Ogun River about $4 \mathrm{~km}$ south of the park holds a very large body of water reaching up to $10 \mathrm{~km}$ or more upstream of Rivers Owu, Ogun and Oowe. Otherwise, all the rivers and streams in the park are seasonal and cease to flow during the dry season. However, the major rivers break into pools some quite large, but the Ogun River maintains a very low discharge rate during this period.
Inspite of the deep entrenchment of Christianity and Islam, the traditional region is still adhered to by a sizeable number of people and both Christians and Muslims also respect this. Thus, various traditional cultural festivals are celebrated at various times of the year. These include Egungun, Sango, Ogun, Oya, Obatala, Oro, Asabari , Antele festivals e.t.c.

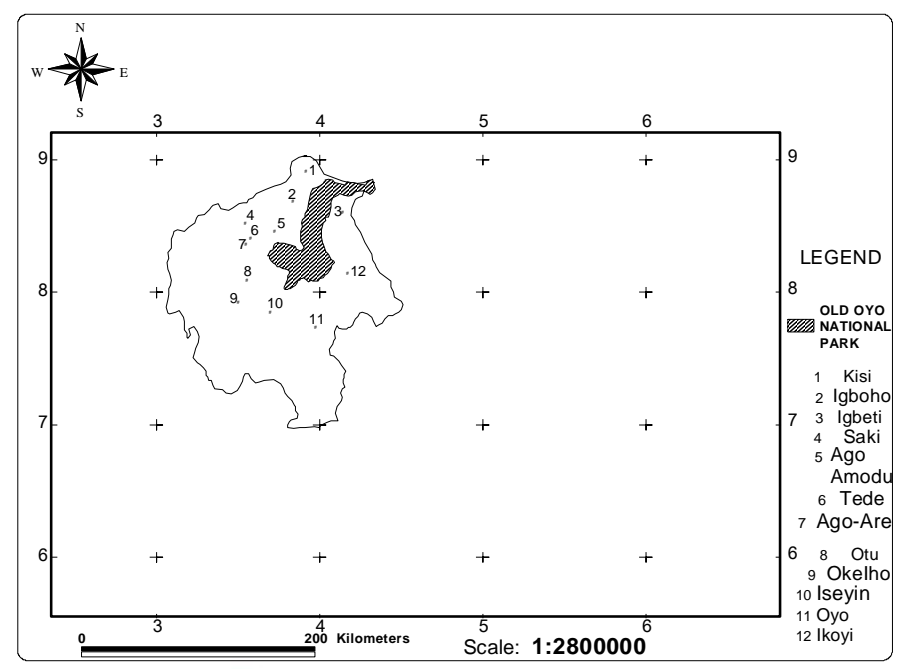

Figure 1: Map of Oyo State showing location of Old Oyo National Park and adjourning communities Source: Computed From 2008/2009 Field Survey

Detail assessments of the level of development of the cultural and natural features in the Park revealed information on their developmental status. This was done based on the three components of tourist destination, viz; attraction, amenities and accessibility. Except for Agbaku cave, Python cave and Kosomunu Hill that were least developed, all others features in Oyo-Ile were regarded as less developed and the obvious reason is because they lack amenities, not attractive although they were accessible only during the dry season. Ikerre Gorge Dam Lake, Ibuya pool were regarded as developing because they were attractive, accessible with limited amenities. There were also those that were completely in ruins with no clear sign/demarcation of the features, these are regarded as Not developed. These resources can be cartegorised into four ecotourism features with their respective elements namely Hydrological formations includes Ikere Gorge dam Lake, Ibuya pool, Agbaku river course, River Ogun , River Iwa, river Tessi and their tributaries, Hand dug well and Water reservoir; Geological formations includes Agbaku cave (Plate 1), Mejiro cave, Python cave (Plate 2), Yemeso hill (suitable for telescopic viewing and climbing expedition) and Kosomonu hill (Plate 4) literally referred to as compass since it assist the inhabitants in locating their destinations in the olden days especially during expedition; Historical/cultural formations like the relics of the old buildings, relics of the Palace, Mejiro grinding site, Outer and inner defense wall, Akeasan market beacon, relics of town hall (Plate 3), Aganju ( King's resting point). Wildlife resources (fauna and flora). 


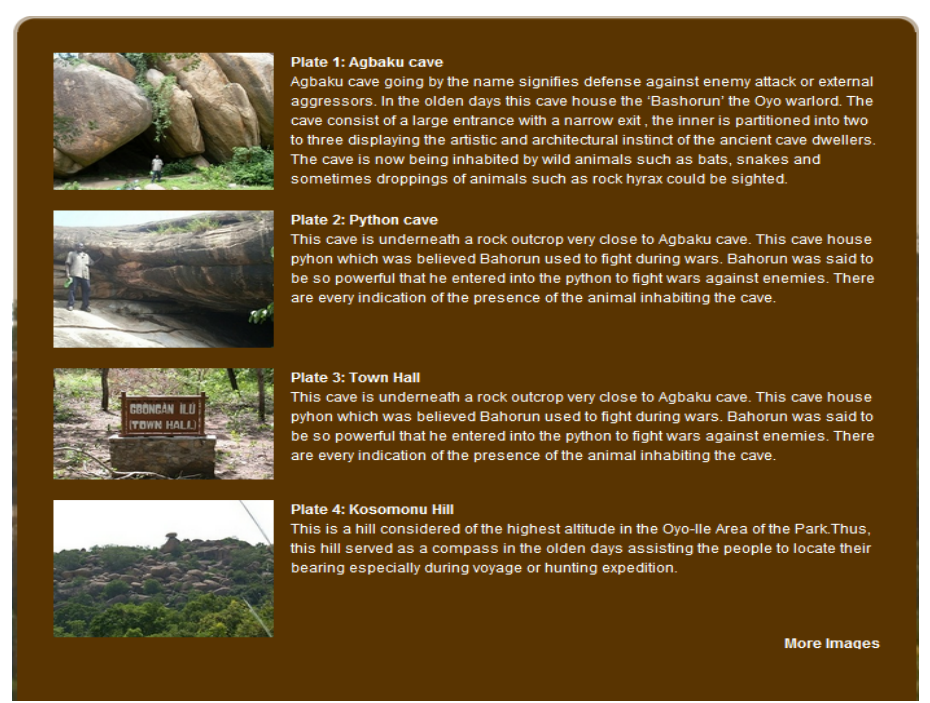

These caves were now being inhabited by wild animals such as Bats (Agbaku cave, Plate 5), python (python cave, Plate 6), Lion ( Mejiro cave Plate 7). Relics of Koso and Sango Royal Dynasty was located at a place over $20 \mathrm{~km}$ away from Oyo-Ile range of the Park in Igbeti. According to Dan (2000), Cultural heritage tourism is being regarded as the fastest growing segments of the tourism industry simply because of its ability to offer tourists unique products that cannot be found elsewhere. Oladeji and Akintola (2010) observed that cultural heritage tourism is a labour intensive industry and creates many job opportunities especially for young people and part time workers. These researchers opined that the most direct economic benefits are the improvement in employment and income.

The results obtained from the appraisal of the fauna and flora resources composition of the Park revealed that species distribution and composition are experiencing decrease and are being threatened by the increasing rate of anthropogenic activities of the host communities around the Park (Oladeji et.al. 2012). This support the findings of Falade (1993) that from the information collected from the officials of the Parks surveyed revealed that the fauna population in the parks were declining fast, Alarape (2001) also recalled that the park for a very long period in the past evidently suffered from mismanagement through destructive activities such as hunting, cattle grazing, logging and uncontrolled burning.

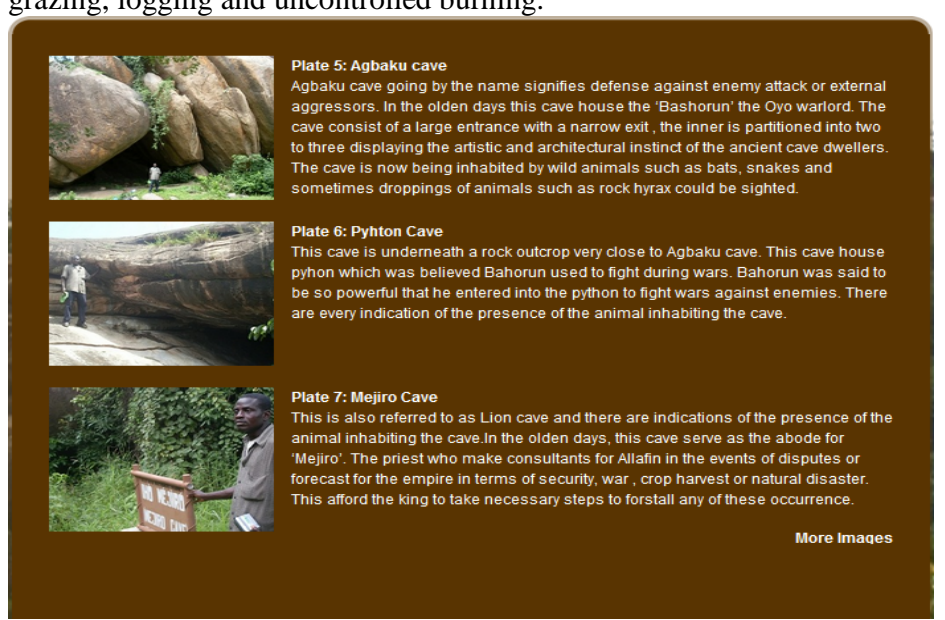

Moreover the flora and fauna resources of the park have been largely depleted leading to extermination of some species (Oladeji et.al. 2012) for instance fifteen species of the thirty eight animals were sighted by Ayodele, (1988), fourteen species were sighted by Afolayan,1996 and fourteen species were sighted by Alarape, (2001). (See Plate 8and 9)

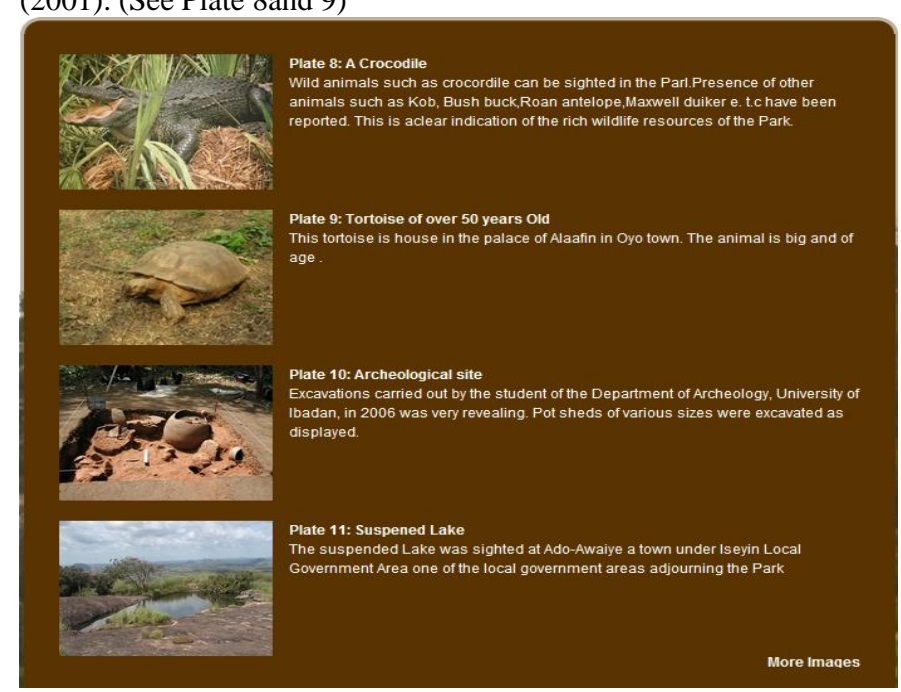

One of the importance uses of Geographical Information System Technique is that it assists in Mapping where things are, thereby let you find places that have the features one is looking for and to see where to take action. The need to make the description of the natural and cultural heritage features location specific with the use of Geographical Information System Technique has necessitated the presentation of a gridded digital map of these features; this will assist tourists from any part of the World to virtually access the identified cultural and historic heritage resources in the Park and those in the adjourning communities. Fig. 2 presents a gridded Map of Historical Sites location of Old Oyo National Park and adjourning communities.

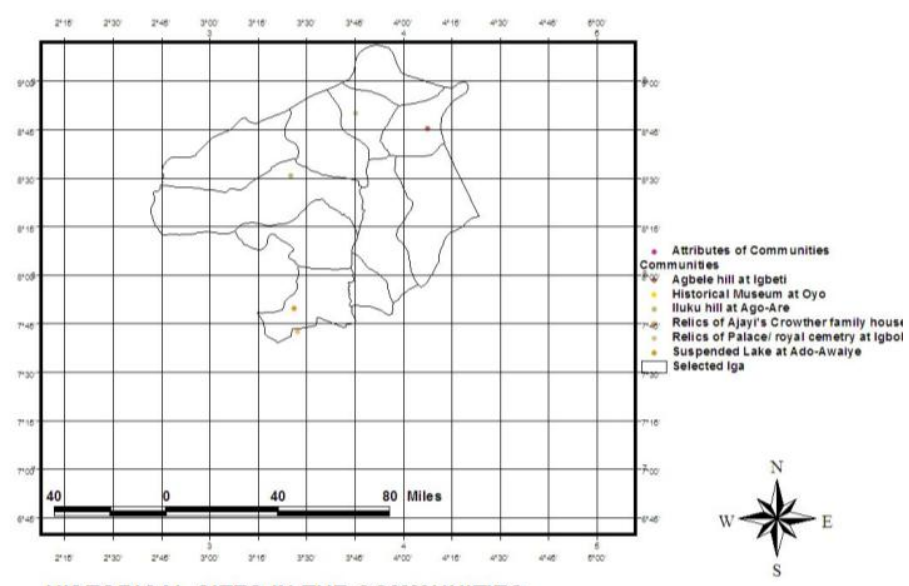

HISTORICAL SITES IN THE COMMUNITIES

Figure 2: Grid Map of Historical Sites in the adjourning communities.

Source: Computed From 2008/2009 Field Survey

Eight cultural festivals and six ceremonies, in addition to intangible cultural acts like oration, greetings, dressing, tribal mark, folklore, taboo, proverbial talk, drumming, acrobatic display and dancing are the rich cultural heritage of the people of the region.

Diversity of plants resources in this park are of immense values to the existence of the host communities in sustenance of their lives through their applications in the treatments of different ailments, 
sources of food, means of generating incomes and their cultural values (Afolayan et. al 2009). Posey (1999) introduced the term biocultural diversity. Understanding the significant role that wild plants play in fulfilling the socio-cultural need of the human would go a long way toward achieving conservation of biodiversity.

The uniqueness, authenticity and genuineness of the cultural heritage resources of the host communities are incomparable with other parts of the country. Traditionalist who are the custodian of the royal cemetery at Igboho were interacted with the aimed of exploring the uniqueness and authenticity of the history of Old Oyo empire dated many centuries ago. Other features identified at Igboho were relics of Alaafin Palace that reigned in Igboho, royal cemetery of past Alaafin and a housing unit where antiquities collected as instruments of power and weapons of war of past Alaafin are kept. Another unique feature in the local communities was Suspended Lake in Ado-awiye a distance of $20 \mathrm{~km}$ from Iseyin (Plate 11). While most of the hotels in Oyo have different categories of facilities for lodging ranging from single room to double room suite and chalets. The case is slightly different in Iseyin town. Facilities in Iseyin are restricted to single and double room with few ones having executive rooms -extra facilities compared with those in the single and double room. Depending on the taste of the tourists, the rate payable per night in these hotels in Oyo was found to range from $\$ 1,400$ - $\$ 8,100$. The rate was found to be lower in Iseyin $\$ 1,300$ - $\$ 3,500$ per night.

\section{LITERATURE REVIEW ON E- COMMERCE}

One of the most important characteristics of electronic commerce is the opportunity and promise it holds for tourism to extend their capabilities and grow. In Chulwon (2004) the study involves the collection of the secondary data regarding e-commerce for the tourism industry. The study considered the challenges and opportunities faced by the tourism industry. It covered e-commerce activities, benefits, barriers and key success factors. According to his result, the main benefits of e-commerce for tourism enterprises are 'providing easy access to information on tourism services,' 'providing better information on tourism services,' and 'providing convenience for customers'. The result also reveal many other benefits of e-commerce, such as 'creating new markets,' 'improving customer services,' 'establishing interactive relationships with customers', 'reducing operating cost', 'interacting with other business partners', and 'founding new business partners'. It is also suggested that there are a number of barriers for tourism in adopting e-commerce. These barriers include 'limited knowledge of available technology,' 'lack of awareness,' 'cost of initial investment,' 'lack of confidence in the benefits of e-commerce', and 'cost of system maintenance.' These barriers also include 'shortage of skilled human resources,' and 'resistance to adoption of e-commerce.' In terms of market situation, one might also mention 'insufficient e-commerce infrastructure,' and 'small e-commerce market size'. In Byron \& Gagliardi (2005) an insight as to why the Internet is yet to be fully exploited for its developmental value in a number of developing economies such as tourism is discussed. The two main factors for conducting successful e-commerce are 'security of the e-commerce system' and 'user-friendly Web interface', thus recognising that building customer trust and convenience for customers are essential to succeed. 'Top management support,' 'IT infrastructure,' and 'customer acceptance' were also considered as an important factors. E-commerce is expected to benefit economic development in several ways, first as noted in Deepthi (2008), e-commerce allows business to reach a global audience. In Africa, for example, the tourism and handicrafts industries are realizing their ability to deliver their product information directly to consumers. Tourist lodges, hotels, and governments across the continent can maintain sophisticated websites advertising their unique features, handling booking order, and promoting specials to interested consumers. Similarly, small manufacturers of traditional handicrafts are discovering how ICTs can assist the marketing and distribution of their wares. Secondly opportunities created by e-commerce and its predecessor technologies is that ICTs can create digital market places to manage supply chains and automate transaction, increasing efficiency and opening previously closed markets to firms in developing countries. Thirdly, e-commerce is improving the culture of business. There are now better intra-firm communications, cost savings procedures, and reductions in the inventory costs leading to better management.

The salient information management economizing features of Internet technology as explained in Wheatley, Buhr, and DiPietre. (2001) are highlighted as follows.

a. The Internet as a communication technology is able to significantly reduce the costs associated with the paper work of organizing trade.

b. Through its open architecture and possibly intelligent software agents, the costs of looking for and gathering information on possible trading partners, is reduced.

c. The need to find suppliers or buyers of proper size is reduced

d. In terms of bilateral relationships between producers and processors, video data and other electronic measurement/monitoring devices, when coupled with the electronic media of the Internet, will reduce the costs of monitoring.

e. There is a lowered informational cost of tracing the flow of products through the production system, i.e., from producer to processor.

f. One could also raise the question as to whether the informational capacities of the Internet could substitute for storage and/or product inventories Milgrom, and John (1988)

\section{E-Commerce for Tourism Design}

The World Wide Web (web) is a client/server application layer on top of the internet that provides simple standard protocols for naming, linking and accessing virtually everything on the internet (Williams et. al 2003). The internet provides a set of interconnected networks for individuals and business to complete transaction electronically (Valacich and Schneider, 2010).

The key technological infrastructure components of the e-commerce includes, the web server hardware platform with the appropriate software is a key e-commerce infrastructure ingredient, the web server must run on an operating system and in addition to this, each e-commerce website must have web server software to perform fundamental service which may include the security and identification, retrieval and sending of web pages, websites tracking, website development and web page development, the e- commerce which supports five core tasks of catalogue management, product configuration, shopping cart facilities, and e-commerce transaction processing and web traffic data, a High Speed connection to Networks and Internet. Internet is the collection of all computers that can communicate using the Internet Protocol suit, with the Computers and Networks registered with the Internet Network Information Centre (InterNIC) (Weijia and Wanlei, 2005). The internet allows communication between millions of connected computers worldwide. Information is transmitted from client PCs whose users request services in response to requests. The internet is a large scale 
client/server system, the client PCs within homes and businesses are connected in the internet via local internet service providers (ISP) which in turn are linked to larger ISPs with connections to the major national and international infrastructures (Barry et. al, 2010).

The e-tourism system has the basic component of catalog of product, shopping cart, check out, payment gateway (payment processing network), customer account, internet merchant account and business account. Customers can browse the catalog of tourism product and shop cart it. The gateway component accept credit card details and send to the payment gateway for authorization on the premise of adequate security using the SSL technology. Funds are reserved into the customer account and later transfer to merchant account, and then to the business account of the park. Figure 3 presents the conceptual diagram of e-commerce model for the park.

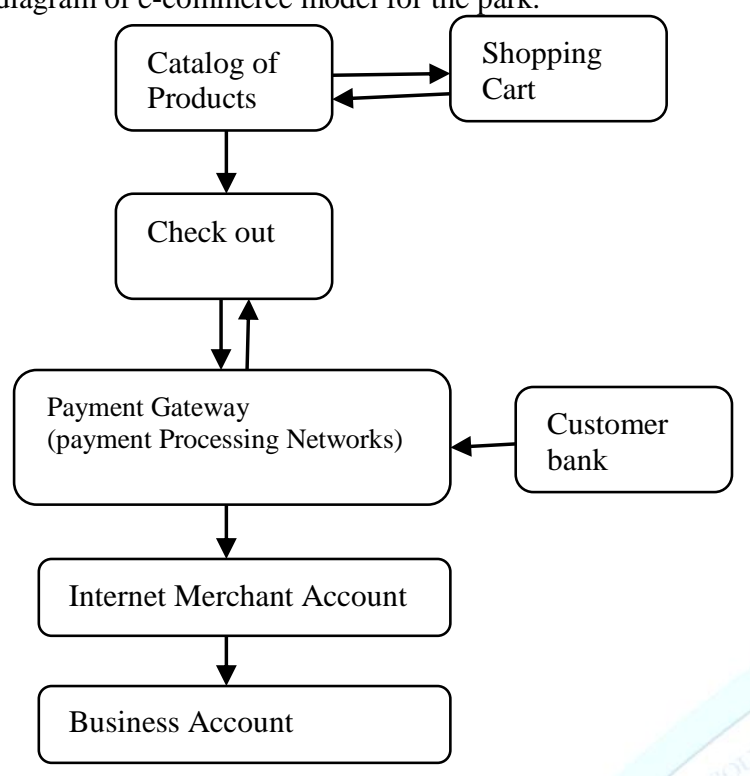

Fig. 3: Conceptual Model of e-Commerce for Old Oyo National

One way to pass logic from a web server to a browser is to write a set of macro like instructions called a script in a scripting language (java scripts). A script might be used to animate an image on a window, highlight an icon, or play an audio file when the mouse pointer moves over a spot on the client screen. Scripts are also used to validate the completeness and accuracy of the data input to a browser-based form. To add more interesting interactivity to a web page, applets, small programs executed from within another program such as a browser can be downloaded to a client. Figure 4 presents ecommerce software to surf for items to purchase from the etourism market place. Here, detailed specification of available products are displyed on a page where customres can make choices to the cart. There is the need for an intending customer to register with the site for user authentication and autorization of the system. The next presentation is on the basic features of the e-tourism system

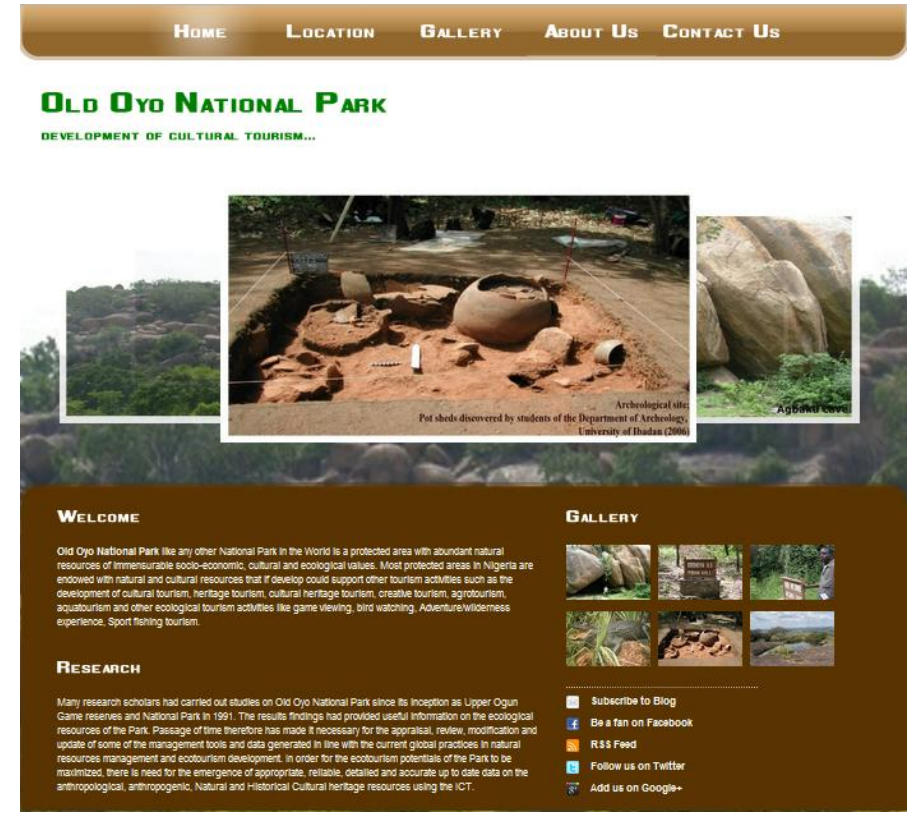

The Electronic Commerce Order Fulfillment Process: The ecommerce ordering fulfillment process starts when the order is received and there after verified, the seven other activities that take place which can be done simultaneously or sequentially including assurance of customer payment, check of in-stock availability, shipment arrangement, insurance, replenishment, in home production, contractor user, contact with customers and returns as exchange of item (Turban and Volonino, 2010). Firewall is necessary to mitigate against associated social and economic risk of e-tourism (Mark, 2009).

Invoice and Shopping Cart: After a customer have chosen all he/she wants to purchase, then an invoive is processed to specify in detailed term what needs to be paid and for what items. Booking can also be included in this module.

Electronic payment subsystem: Payments are an integral part of business, whether in the traditional way or online. The most common methods as discussed in Turban and Volonino (2010) for electronic payment system in E-commerce includes the Electric credit card, Electronic bill payments (Online banking, Biller direct, Bill consolidator), E- Wallets (digital wallets), Virtual credit cards, Payment using finger prints. Details discussion in Turban and Volonino (2010). The system employed the VISA and the Mastercard card that are recently available in most of the Nigerian Banks.

In Mark (2009) there are several network security devices that can be used to protect the network from attacks. These include firewalls, proxy servers, honey pots, network intrusion detection systems, host and network intrusion prevention systems, protocol analyzers, internet content filter and integrated network system hardware.

The next session presents the page content of the application. This includes Watersheds and Drainage Patterns frame, Culture act/cultural events frame, Art and Crafts, Calabash Carving, Leather works and Iron Smelting

Layout of the e-commerce for Tourism Watersheds and Drainage Patterns frame. There are three watersheds in Old Oyo national Park, that of River Ogun and its numerous tributaries, that of River Tessi and its tributaries and that of River Iwa and its tributaries. Ogun River flows southwards to the Atlantic Ocean. Several tributaries notably Oopo, Iwawa, Oowe and Owu flow southwestwards and southeastwards to join it before its exit from the 
park. The Tessi River flows northwards to the River Niger. Three main tributaries including River Soro join it before its exist from the park. The Iwa River flows northeastwards to the River Niger (See Fig 5).

Surface Water Frame. The construction of a dam at Ikere Gorge on the Ogun River is about $4 \mathrm{~km}$ south of the park holds a very large body of water reaching up to $10 \mathrm{~km}$ or more upstream of Rivers Owu, Ogun and Oowe. Otherwise, all the rivers and streams in the park are seasonal and cease to flow during the dry season. However, the major rivers break into pools some quite large, but the Ogun River maintains a very low discharge rate during this period.

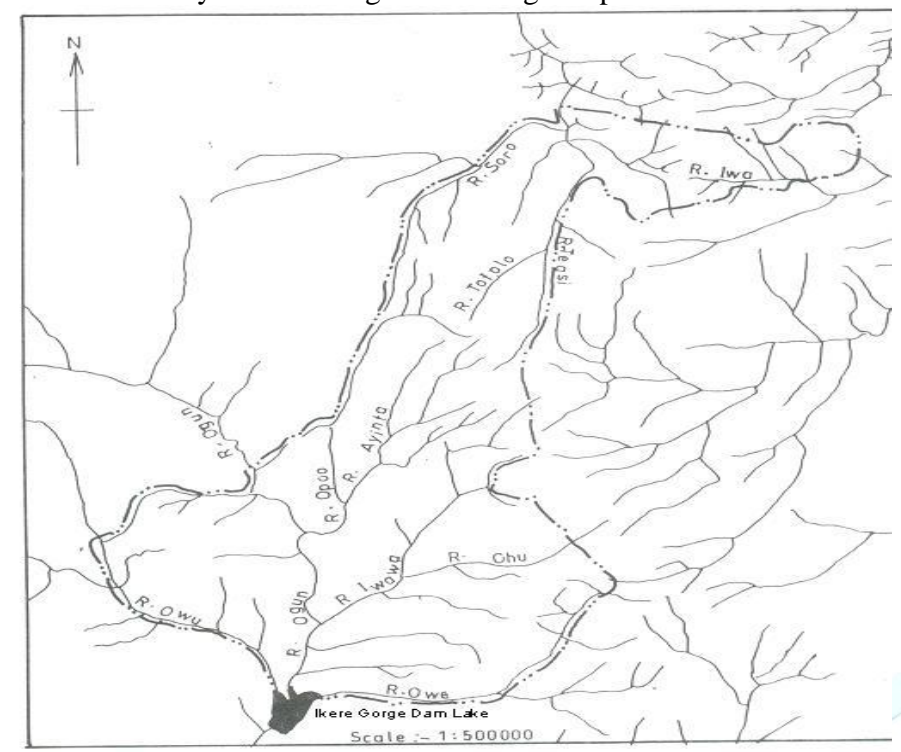

Figure 5 : Map of Old Oyo National Park showing the drainage Pattern

Source: Afolayan et.,al, 1996

The Old Oyo National Park can be categorized into five ecotourism features as presented in Table 1. While Table 1 presents the list of Natural and Cultural Heritage Resources outside the Park with their GPS readings.

Table 1: Old Oyo National Park can be categorized into five ecotourism features

\begin{tabular}{|c|c|}
\hline $\begin{array}{l}\text { Hydrological formations } \\
\text { Ikerre Gorge Dam Lake } \\
\text { Ibuya pool } \\
\text { Agbaku river course, River Ogun, } \\
\text { River Iwa, Tessi and their } \\
\text { tributaries } \\
\text { Hand dug well } \\
\text { Water reservoir }\end{array}$ & $\begin{array}{l}\text { Geological formations } \\
\text { Agbaku cave } \\
\text { Mejiro cave } \\
\text { Python cave } \\
\text { Kosomonu Hill } \\
\text { Yemeso Hill }\end{array}$ \\
\hline $\begin{array}{l}\text { Historic /Cultural formations } \\
\text { Relics of Palace } \\
\text { Akesan Market beacon } \\
\text { Town Hall } \\
\text { Koso } \\
\text { Abandoned settlement/ relics of } \\
\text { buildings } \\
\text { Outer defense wall }\end{array}$ & $\begin{array}{l}\text { Wildlife resources } \\
\text { Fauna } \\
\text { Flora }\end{array}$ \\
\hline
\end{tabular}

Table 2. List of Natural and Cultural Heritage Resources outside the Park with their GPS readings

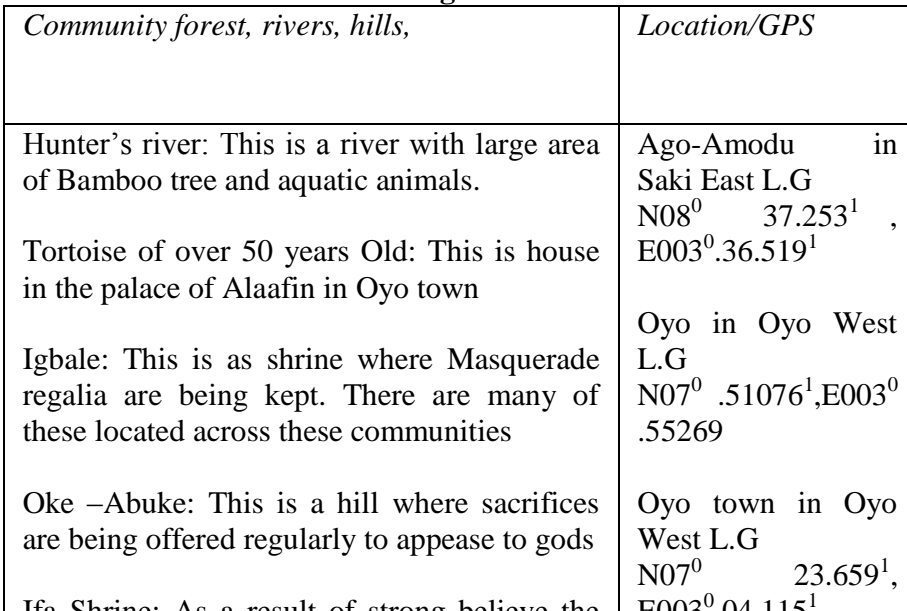

Ifa Shrine: As a result of strong believe the people in these communities have in their tradition especially the people of Oyo town there quite a good number of Ifa shrine sited across the town especially in Isale Oyo area of the town

Burial site of past Obalufon (title of king) of Sepeteri/Obalufon/Orisa nla shrine

Relics of Alafin Palace in Igboho

Royal Cemetery of past Alafin that reigned in Igboho

\section{Suspended Lake}

Relics of Bishop Ajayi Crowder's

Family house at Osoogun

Slave terminal (Iyalode)

Adasonia digitata of over $30 \mathrm{~m}$ dbh

Oke-Agbele
Oyo town in OyoWest

Oyo town in Oyo West L.G

$\mathrm{N} 07^{0} 23.659^{1},{\mathrm{E} 003^{0}}^{0}$ $04.115^{1}$

Sepeteri in Saki East LG

$\mathrm{N} 008^{0} \quad 37.331^{1}$, ${\mathrm{E} 003^{0}}^{0} 38.589^{1}$

Igboho in Oorelope LG

N008 $8^{0} .83400^{1,}$

${\mathrm{E} 003^{0}}^{0} .1550^{1}$

Igboho in Oorelope LG

$\mathrm{N}^{0} 08^{0} .83400^{1,}$

$\mathrm{E}_{003}{ }^{0} .1550^{1}$

Ado-awaye

Iseyin LG

$\mathrm{N}^{0} .82797^{1,} \quad \mathrm{E}^{\prime} 003^{0}$ $.43813^{1}$

Osoogun in Iseyin LG

$\mathrm{N} 7^{0} .70820^{1,} \quad \mathrm{E}^{2} 03^{0}$ $.45572^{1}$

Osoogun in Iseyin LG

N008 ${ }^{0} .83400^{1}$,

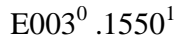

Igbeti

Olorunsogo LG

N008 $8^{0} .75440^{1,}$

$\mathrm{E} 004^{0} .1261^{1}$ 


\section{Culture acts / cultural Events Frame}

Eight cultural festivals including Egungun, Yam festival, Sango, Ogun, Oro were identified to be celebrated at different part of year. In addition to these, Cultural acts practiced in these communities include, tattooing, tribal mark on faces, folklore among the children, dancing, acrobatic display, magicians and drumming in many occasions, proverbial talk among the elders, celebrities associated with group appearance or attire, Traditional mode of dressing, ewi/oration , greetings, Ayo-tita, taboo and Yam Festival in Tede (Plate 11).

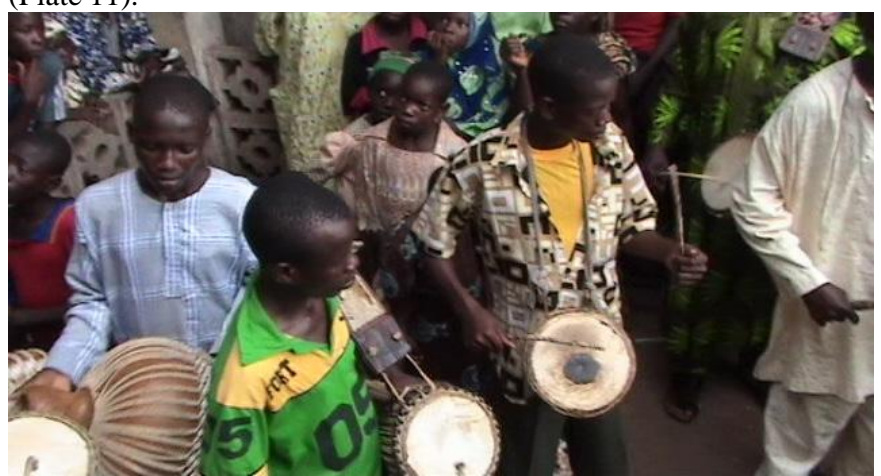

Plate 12: Yam festival Cultural festival in Tede

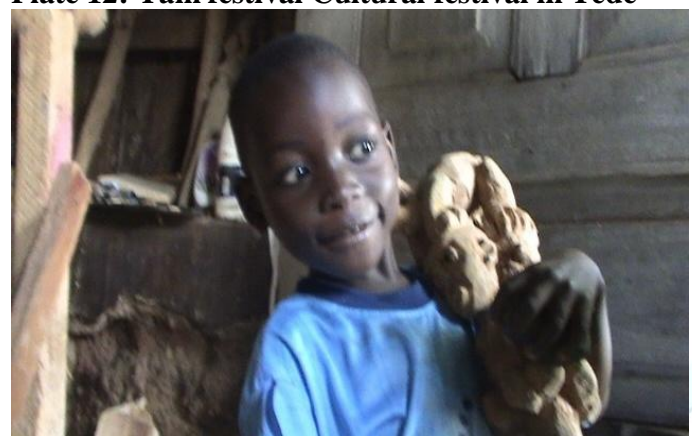

Plate 13: Sculptural work

\section{Art and Crafts Frame}

Some of the notable Art and Craft in the neighbouring communities include Wood carving or sculptural work( Plate 13), Cloth weaving, leather work, Calabash carving, bid and cowries making.

Sculptural work:

The names of their products that could serve as souvenirs to the visiting tourists include symbols of Idols such as Sango (Plate 13), Oya, Ifa; Opon ifa (plate 14), Oroke ifa, decorating wooden frame, Twins wooden image and Wooden pen. Other products include Opon-Ifa, Opon ayo (Plate 15), Staff or walking stick.

\section{Calabash carving Frame}

Calabash carving is practiced in Oyo town than in any other parts of the communities. This has given credence to Oyo town as the home of calabash. Other town where calabash carving is practiced is Igbeti however the type of calabash carved were different from those in Oyo town. Hausa types of calabash (Plate 17a and 17b) were being carved in Igbeti while Yoruba type of calabash (Plate 18) were being carved in Oyo.This is a clear indication of ethnic diversity that occur across these communities with large concentration of Hausa-Fulani in the Northern part than the Southern part where majority are Yorubas . Some of the materials used for production in Oyo includes Ahan (small axe), Afinnan (Small knife), Ikoko (Small blade), Iregba (Knife), Ipa igba (small knife), Ita igba (small chisel).

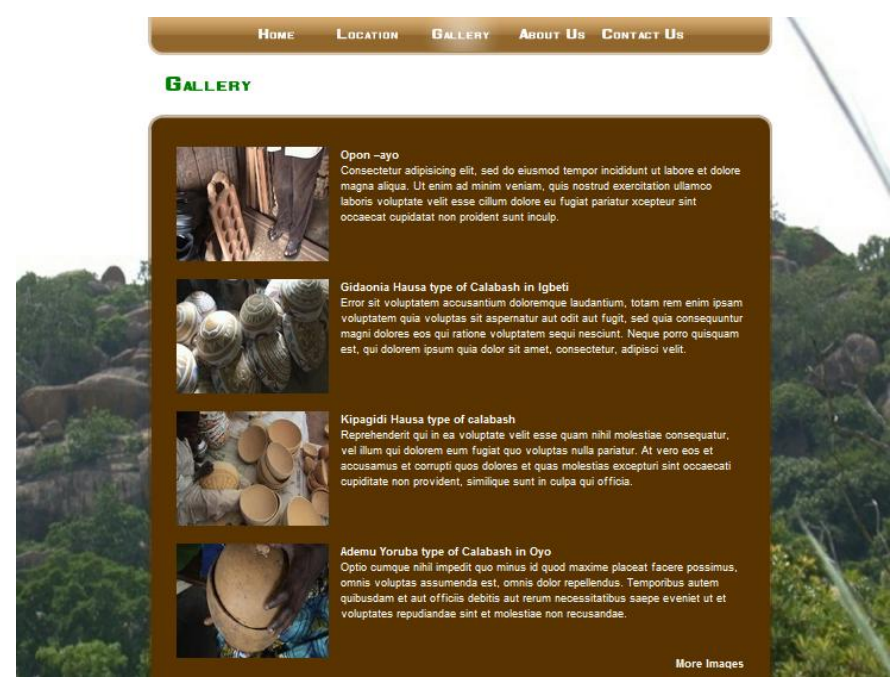

\section{Leather works Frame}

Leather work is practiced in Oyo and Saki. However this practice was peculiar to Oyo town. List of names, type and leather work is presented in Table 3.

Table 3: Names and types of Leather works

\begin{tabular}{|c|c|c|c|}
\hline & $\begin{array}{l}\text { Type of leath } \\
\text { Local name } \\
\text { name }\end{array}$ & English & Material being used \\
\hline I & Abebe & Hand fan & $\begin{array}{l}\text { Goat and cow skin peacock } \\
\text { feather }\end{array}$ \\
\hline Ii & Timutimu & $\begin{array}{l}\text { Leather cushion } \\
\text { seat }\end{array}$ & Goat and cow skin \\
\hline iii & $\begin{array}{l}\text { Apo/ } \\
\text { Apamo }\end{array}$ & Pulse/hand bag & Goat and cow skin \\
\hline iv & Irukere & N/A & $\begin{array}{l}\text { Wooden stick and goat/cow } \\
\text { skin }\end{array}$ \\
\hline
\end{tabular}

\section{Iron Smelting}

Iron smelting is practiced in all towns and villages surrounding the Park, although the activity is peculiar to Saki where it was learnt that business originated from Ghana. It is significant to see the name SAKI boldly written on the Products. Different types of products were identified ranging from cooking utensils of various sizes to other domestic items (Plate 19a and 19b)..

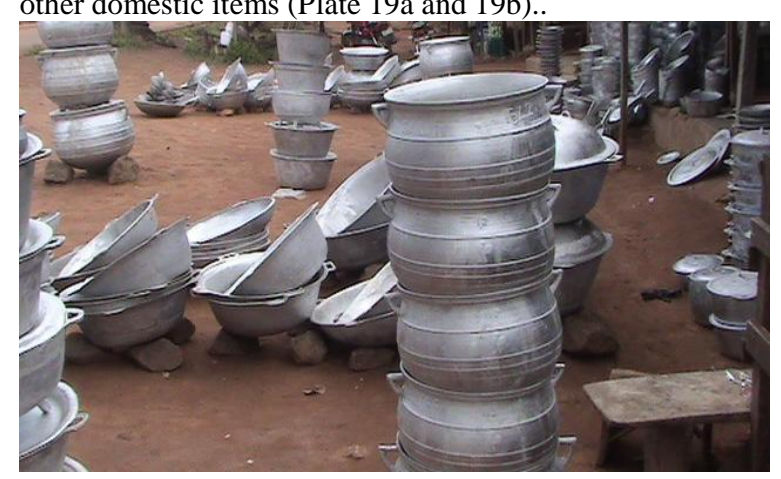

Plate 19a:Iron Smelting in Saki 


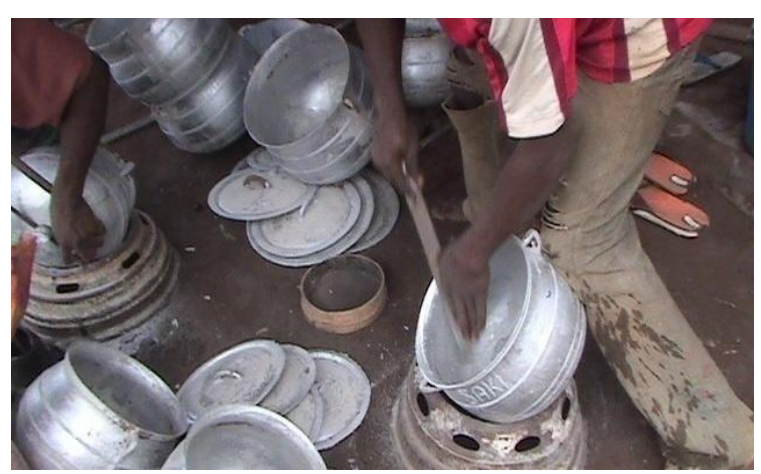

Plate 19b: Iron pot business in Saki

\section{CONCLUSION}

Contemporary information society has made Toursim a highly information-intensive industry as ICT has a potential impact on tourism business. The role of ICT in tourism industry cannot be underestimated and it is a crucial driving force in the current information driven society. It has provided new tools and enabled new distribution channels, thus creating a new business environment. ICT tools have facilitated business transaction in the industry by networking with trading partners, distribution of product services and providing information to consumers across the globe. On the other hand consumers are also using online to obtain information and plan their trip and travel.

Old Oyo National Park (OONP) is a unique Protected area containing natural and cultural heritage resources it could be referred to as a Mixed Heritage Site according to UNESCO. The International treaty called the Convention concerning the Protection of the World Cultural and Natural Heritage adopted by UNESCO in 1972 described Mixed Heritage sites as properties with both outstanding natural and cultural values. OONP is endowed with abundant natural resources of immensurable socio-economic, cultural and ecological values. However, these values may be harnessed with e-commerce. The prototype etourism using the Old Oyo National Park has the basic features of catalog of product, shopping cart, check out, payment gateway (payment processing network), customer account, internet merchant account and business account. Customers can browse the catalog of tourism product and shop cart it. The gateway component accepts credit card details and sends to the payment gateway for authorization on the premise of adequate security using the SSL technology. Funds are reserved into the customer account and later transfer to merchant account, and then to the business account of the park.

\section{REFERENCES}

[1] Adetoro .A.O. (2001). Study on Socio-Economic factors in the Management of Old Oyo National Park. Unpublished $\mathrm{PhD}$ Thesis Submitted to the department of Wildlife and Fisheries, University of Ibadan

[2] Adeyemo A.I. (1993). Study on some aspects of Ecology of Baboon in Old Oyo National Park. Unpublished Ph.D Thesis Submitted to the Department of Wildlife and Fisheries, University of Ibadan

[3] Afolayan, T A., Agbelusi E. A.,Ayodele,I.A., Balogun, A.M., Soladoye , M.O., Agbaje -Williams,B., Fasakin,E.A and Ogunmodede, M.S.(1996). Management Plan of Old Oyo National Park pp215.

[4] Afolayan, T. A and Agbelusi E, A and Oladeji. S. O (2009). Medicinal Plants of economic values to the Host communities of Old Oyo National Park Proccedings of School of Agriculture and Agricultural Technology at Federal University of Technology , Akure 21st-23rd April,2009

[5] Alarape. A. (2001). Culture and Conservation in and around Old Oyo National Park. Unpublished PhD Thesis Submitted to the Department of Wildlife and Fisheries, University of Ibadan.

[6] Areola, O. (1982). A Vegetation Map of Nigeria in Nigerian Maps (K.M Barbor,J.S Oguntoyinbo, J.O.C Onyemelukwe and J.C.Nwarfor , (eds), Hodder and Stonghton, publishers UK Pp 24-25

[7] Ayodele A.I. (1988). Ecological basis for the management of Old Oyo National Park Ph.D Thesis Sumitted to the Department of Wildlife and Fisheries, University of Ibadan.

[8] Babatunde D. O and Aminu R. (1999). Field Guide to Nigerian Freshwater Fishies. Fed. College of Freshwater Fisheries Tech.New Bussa, Nigeria.

[9] Barry M. Leiner, Vinton G. Cerf, David D. Clark, Robert E. Kahn, Leonard Kleinrock, Daniel C. Lynch, Jon Postel, Larry G. Roberts, Stephen Wolff (2010). A Brief History of the Internet, Published by Internet Society. http://www.isoc.org/internet/history/brief.shtml.

[10] Bocij Paul, Greasley Andrew and Hickie Simon (2008). Business Information Systems. Technology, Development \& Management. Prentice Hall Publisher, 4th Edition.

[11] Chulwon Kim (2004) E-TOURISM: AN INNOVATIVE APPROACH FOR THE SMALL AND MEDIUM-SIZED TOURISM ENTERPRISES (SMTES) IN KOREA. Organization for Economic Co-operation and Development (OECD). Italy.

[12] Dan R.(2000). Cultural Heritage Tourism. Practical applications. Museum Associations of Arizona, Arizona Humanities Council pp1-30

[13] Deepthi Shanker (2008). ICT and Tourism: Challenges and Opportunities. Conference on Tourism in India Challenges Ahead, 15-17 May 2008, IIMK. Pg 50-57.

[14] Denman R. (2001). Guidelines for Community Based Ecotourism Development, WWF

[15] Falade, G. O. (1993). Socio-Economic Evaluation of Wildlife Based Tourism Development. In selected Conservation Areas in Nigeria (Unpublished PhD Thesis), submitted to the Department of Wildlife and Fisheries, University of Ibadan, Ibadan, Nigeria

[16] Frederico Neto (2003). Approach to Sustainable Tourism Development Moving Beyond Environmental Protection.DESA Discussion Paper No.29

[17] George, E.W and Reid D.G (2005). The power of tourism: A metamorphosis of community culture. Journal of Tourism and Cultural Change 3 (2), 88-107

[18] Inge M.. Kloppiing and Earl McKinney (2004). Extending the Technology Acceptance Model and the TaskTechnology Fit Model to Consumer E-Commerce. Information Technology, Learning, and Performance Journal, Vol. 22, No. 1, Spring 2004. pg 35-48

[19] Mark Ciampa (2009). Security + Guide to Network Security Fundamentals. Course Technology Cengage Learning. 3rd Edition.

[20] Nigeria Tourism Development Master Plan (2006). Institutional capacity strengthen to the Tourism sector in Nigeria. Final report. vol. 1 
[21] Oladeji and Akinrinola (2010). Potentials of Cultural Heritage tourism as basis for sustainable heritage site Development in Nigeria. Journal Applied Tropical Agriculture,vol15,pp 7-9

[22] Oladeji, S. O, Afolayan , T. A and Agbelusi E, A (2011). Survey of Ecotourism potentials of Old Oyo National Park. ROAN The journal of Conservation Vol.5 180-190.

[23] Oladeji, S. O, Agbelusi E, A and Trevelyan, R (2012). Anthropogenic activities threatening the Management of the Ecotourism resources in Old Oyo National Park, Nigeria. Ethopian Journal of Environmental Studies and Management vol 5. No 1, pp. 100-111

[24] Ormsby, A and Mannle, K. (2006). Ecotourism benefits and the role of local guides at Masola National Park, Madagascar. Journal of Sustainable Tourism 14 (3), pp271287

[25] Popescu Delia (2007). Tourism and e-commerce. Amfiteatru Economic. pg 167-171

[26] Posey, D.A. (1988). The declaration of Beleem. In: Proccedings of the $1^{\text {st }}$ International Congress of Ethno biology. Posey, D.A and W. Overal Ed. Muse Paraense Goeldi Beelem.
[27] Posey, D.A. (1999). Cultural and spiritual values of biodiversity. A complementary contribution to the global biodiversity assessment in cultural and spiritual values of biodiversity. Posey D.A. Ed. 1-9, UNEP and Intermediate Tech. Publications, London.

[28] Turban Efraim and Volonino Linda (2010). Information Technology for Management. John Wiley \& Son, Inc. 7th Edition.

[29] Weijia Jia and Wanlei Zhou (2005). Distributed Network Systems from Concepts to Implementation. Springer. ISBN $0-387-23839-5$

[30] Wheatley, W.P., B. Buhr, and D. DiPietre. (2001). "ECommerce in agriculture: development, strategy, and market implications," Department of Applied Economics, University of Minnesota, Staff Paper P01-6.

[31] William S. Davis and John Benamati (2003). E-commerce Basics: Technology Foundations and E-Business Application. Addison Wesley.

[32] Turban, Lee, King and Chung (2000)

[33] Christoph Schneider and Joseph Valacich (2010). Information Systems Today, Information Systems, Digital World, $4^{\text {th }}$ Edition. Prentice Hall. 